\title{
DEVELOPING A CONTEMPORARY CURRICULUM FOR UNDERGRADUATE NURSING LEARNER SUCCESS
}

\author{
Karole Hogarth and Donna Burkett
}

\section{INTRODUCTION}

The development of a nursing curriculum that prepares nursing graduates to address both current and future health needs of our communities, whilst meeting requirements set by the Nursing Council of New Zealand (NCNZ), New Zealand Qualifications Authority (NZQA) and the Tertiary Education Commission (TEC), is not an undertaking for the faint of heart. This article describes the journey of a curriculum review in a Bachelor of Nursing (BN) degree in the New Zealand context. It was important to share the learning from this process and to show the importance of transparency and teamwork, and that research and maintaining currency in the health environment were essential components.

In the School of Nursing (SoN) | Te Kura Tapuhi at Otago Polytechnic (OP) | Te Kura Matatini ki Otago, the 2020 curriculum review was initiated due to the regulatory requirements for a five-year review cycle. From experience, this process proved to be lengthy and required careful consideration, hence it was commenced in 2018. The nursing curriculum at $O P$ is built from a 30-year history of learner success supported by the guiding philosophy of critical social theory which was relevant when nursing transitioned from an apprenticeship-based model to a tertiary diploma. Our focus for the 2020 curriculum review was to contemporise this philosophy by incorporating important aspects of nursing theory that are relevant in twenty-first century clinical environments locally and globally.

Critical social theory is well integrated into many ways of thinking within the health environment, however our perspective was that Habermas' theoretical system no longer met contemporary thinking. Literature suggests that contemporary nursing curricula require graduates to possess criticality by using established frameworks such as clinical judgement and clinical reasoning (Levett-Jones, Hoffman, Dempsey, Yeun-Sim Jeong, \& Noble, 20I0; C. Tanner, 2006; T. Tanner, 20I0; Lasater, 2007). These nursing frameworks allow learners to become reflective practitioners whilst understanding what it means to become a nurse within a safe supported learning environment.

Further literature reviewed, both locally and internationally, indicates that contemporary nursing curricula are essential in the maintenance of currency for graduates and academics, and uphold and align with the World Health Organisation (WHO) targets and the United Nations (UN) sustainable development goals, which include interprofessional education and sustainability goals. Curricula must also address health targets and specific focus areas set nationally by the Ministry of Health as well as be guided by the NCNZ core competencies and the BN graduate profile.

To ensure that the elements mentioned above were considered in the review process required significant engagement with the academic team. We also had to be cognisant of the requirements of our governing body, stakeholders and communities. The curriculum needed to be focussed and fit for purpose but flexible and adaptable to be able to change as necessary in response to the healthcare environment nationally and globally. 
We were aware the graduate profile for $\mathrm{BN}$ programmes in New Zealand had been recently revised. This allows for individual tertiary provider curriculum delivery to be related to the varying community health and wellbeing requirements, which can differ widely across the country.

Of utmost importance however, was that throughout the curriculum review process, it was vital to acknowledge and respect the contribution of our academic nursing colleagues (tipuna) that had brought the curriculum to such a positive place, as demonstrated by our consistently excellent learner outcomes. Acknowledgment of this rich history enabled a successful launch pad for the contemporary development of a revised curriculum.

\section{CURRICULUM REVIEW PROCESS}

The development of the Curriculum Review Team (CRT) began with the Head of School and Curriculum Leader nominating the three programme leads from each of the self-leading teams within the BN programme at OP. In turn, each programme lead then nominated one further member from each of their teams. The purpose of this was to ensure that future reviews have team members that understand the process which allows succession planning to occur simultaneously. The CRT was also complemented by administrative support and inclusion of the school's dedicated learning and teaching specialist from OP's Learning and Teaching Development team.

Initial CRT meetings helped to determine a clear goal of what was to be achieved, provided an overview of the entire review process, and established an expected timeline (Figure I) of outputs and associated responsibilities. All meetings were minuted and made available on a shared access drive for all staff to access at any time to ensure transparency of the process and to demonstrate accountability. All the progress of the CRT was further communicated to SoN staff at our monthly staff meetings as a standing agenda item.

\section{OP SoN Curriculum Review Timeline}

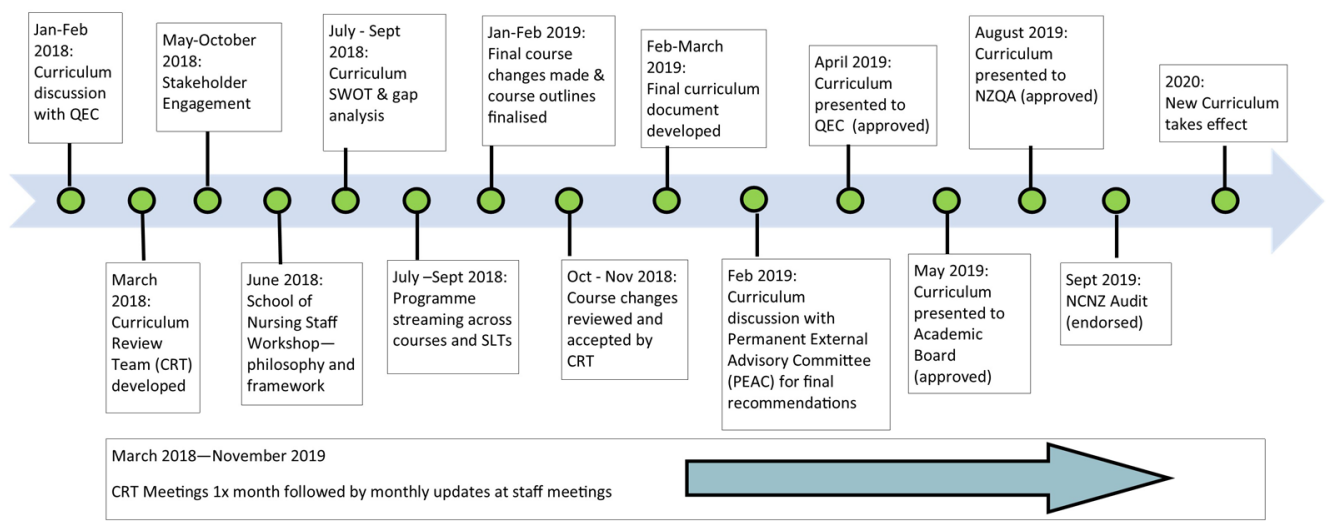

Figure I. Curriculum Review Timeline.

One of the first tasks for the CRT was to undertake a research review of contemporary nursing practice and the development of nursing theories and philosophies to ensure a broad perspective was considered. This enabled a robust discussion of potential theories and philosophies that would best meet the contemporary requirements of the nursing profession in New Zealand and global contexts, both now and into the future. These theories and philosophies are explored further in the Discussion section. 
Simultaneously with the research review, a critical aspect of this curriculum review process began by seeking wider stakeholder involvement. This stakeholder group included our current and past nursing students, our clinical practice partners across all health care sectors, Kaitohutohu, Permanent External Advisory Committee (PEAC) members, the Ministry of Health and SoN staff. This stakeholder engagement and resulting discussions were grouped in datasets and then analysed into themes using a SWOT framework (strengths, weaknesses, opportunities, threats). This helped to identify strengths, weaknesses, opportunities and threats of the current curriculum and potential priorities for the future curriculum. This analysis was further supported by recent external monitor reports and contextualised around the local, national and global healthcare context and it ensured challenges that this raised for the nursing profession were addressed within the review process.

The resulting outcome of both the research review and stakeholder engagement group discussions was the development of a new contemporary philosophy summary statement. The draft philosophy introduced contemporary nursing theories that would become the core component of the curriculum. The nursing theorists that the SoN chose by consensus, following research and robust internal discussions, were Tanner (2006), Lasater (2007) and Levett-Jones et al. (20 I0), all of whom had developed visual tools that both learners and academic staff could articulate and apply to practice.

It was important that this new philosophical direction was supported well by associated rationale for challenging the status quo whilst still paying respect to our tipuna. This philosophy was launched to our SoN staff at a dedicated curriculum review workshop, where further discussion and input was considered to help finalise our future direction.

Once agreed upon, key components and aspects within the new philosophy statement were identified to assist in guiding the creation of the new curriculum framework. The remainder of the workshop then focussed on creating visual representations of concept frameworks by the SoN staff in attendance. There were four self-assigned groups who discussed and created four concept designs. Each of the four designs was presented back to the wider group, including their discussion, narrative and rationale for their chosen design (Figures 2-5). Each presentation was recorded, with permission of each group, to allow for review by staff who had been unable to attend. The model that best aligned with the future vision of our SoN team was then decided on by majority vote.

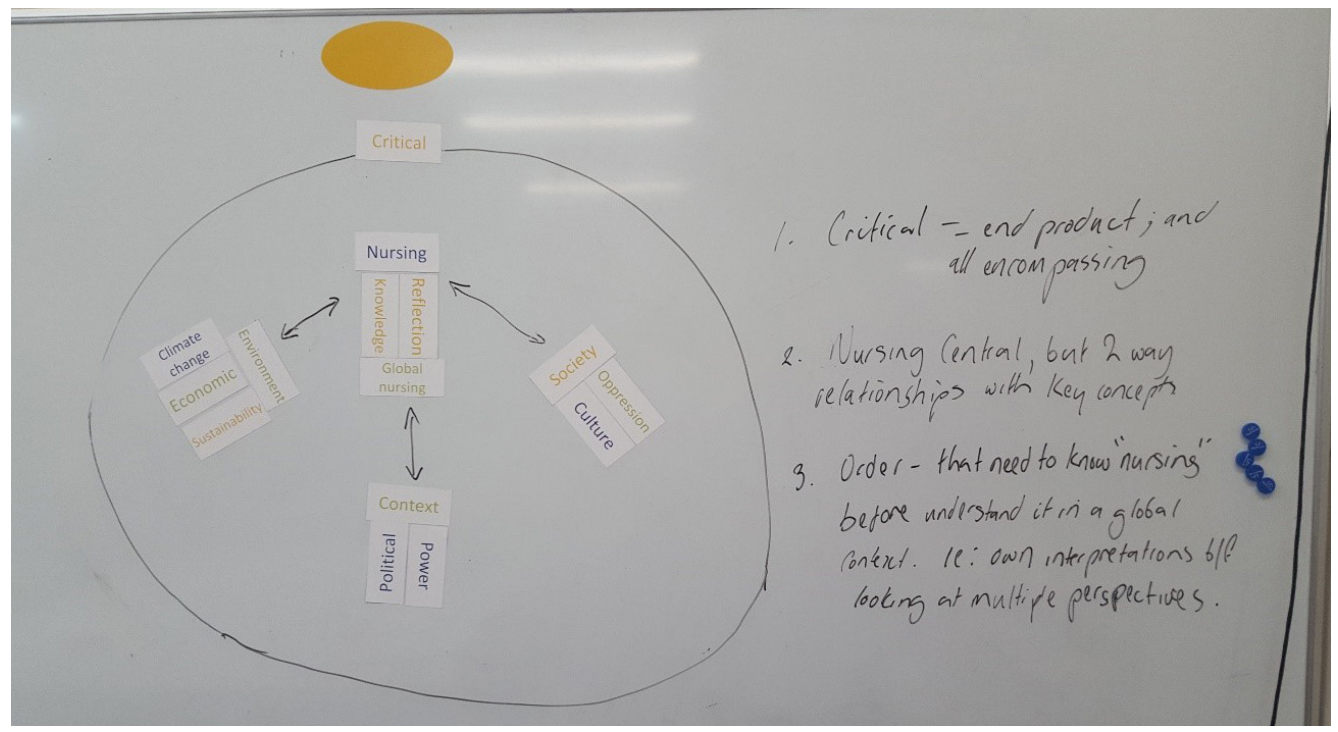

Figure 2. Concept frameworks (a). 


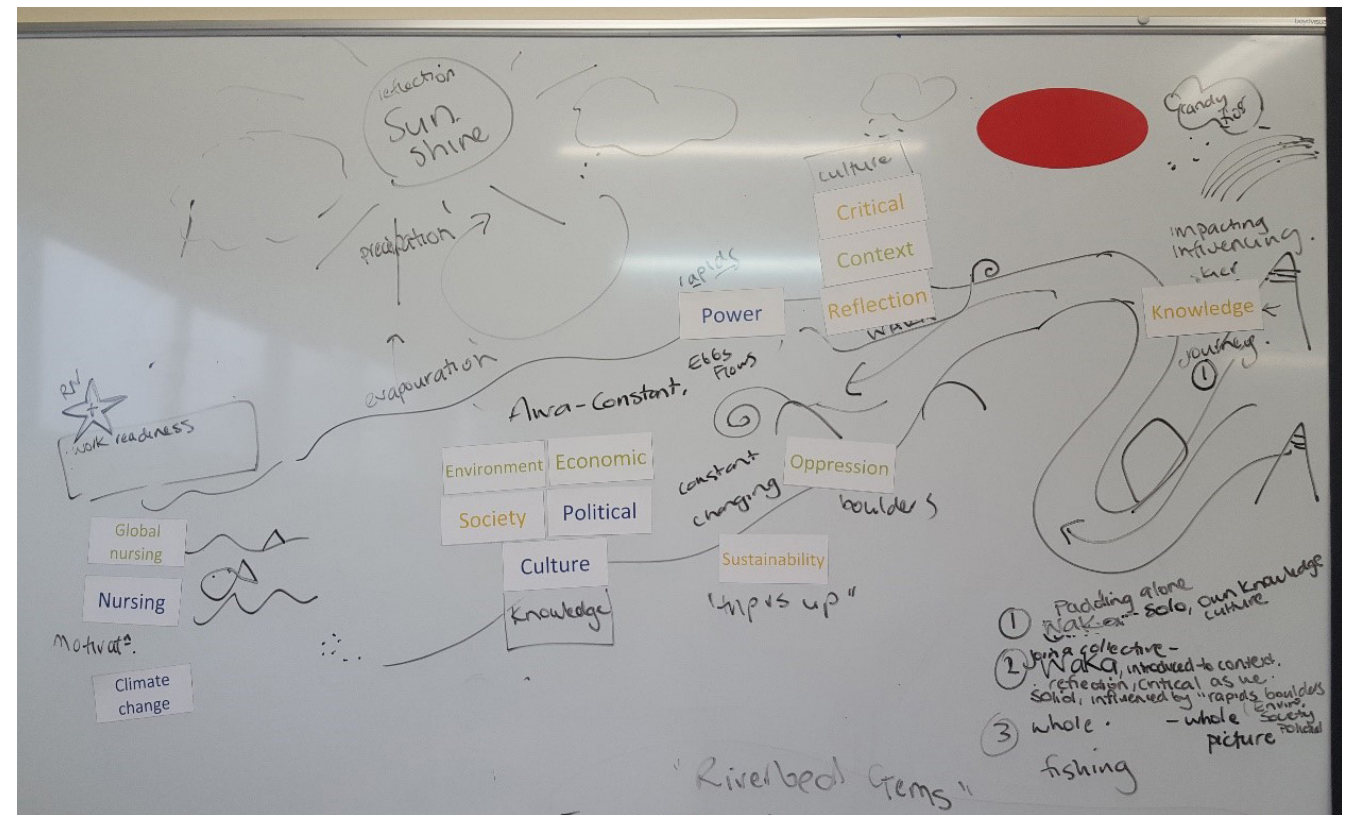

Figure 3. Concept frameworks (b).

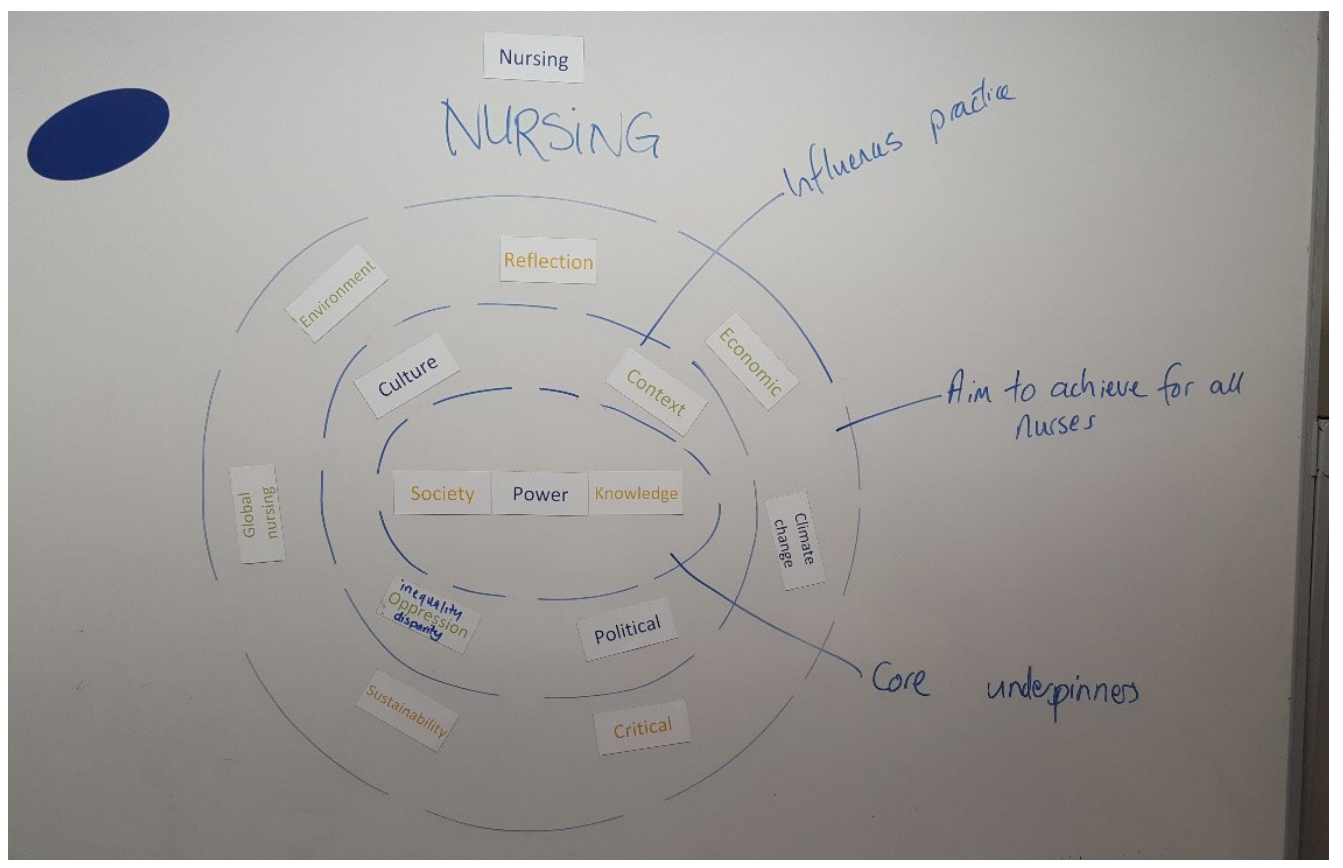

Figure 4. Concept frameworks (c). 


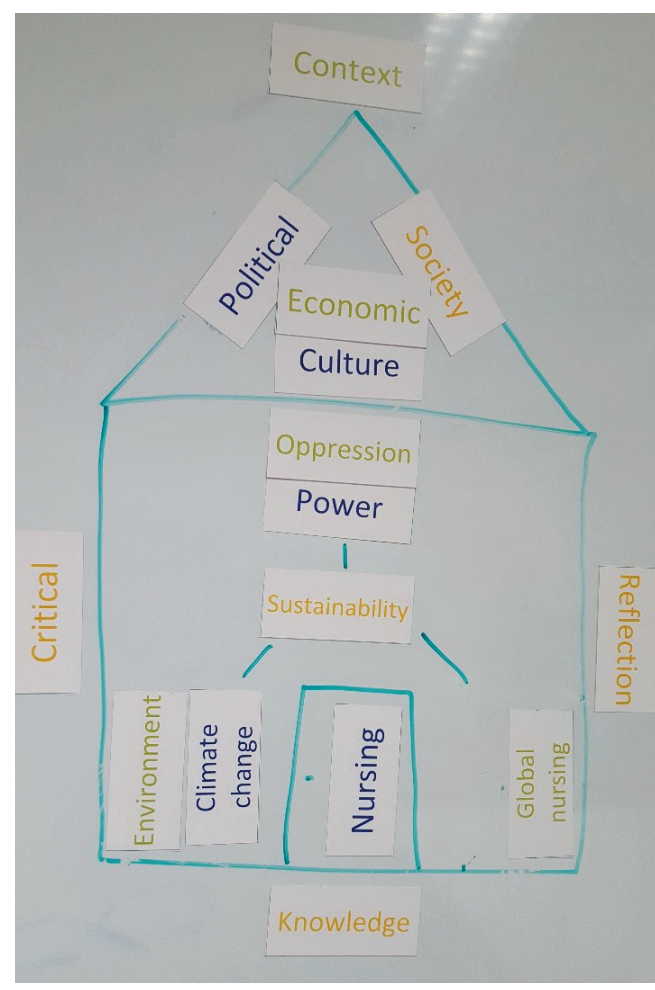

Figure 5. Concept frameworks
The four framework designs were developed by the SoN team during a curriculum workshop. This shows the depth of thinking and collaboration in this process.

The preferred final framework for practice design was decided by democratic vote by the SoN team. The design was then enhanced with the support of the OP Visual Design Team resulting in a visual that was incorporated into the curriculum document (Figure 6).

Once the guiding philosophy and framework for practice using a competency-based curriculum model were decided, the hard work began. Each course within the $\mathrm{BN}$ programme was reviewed in turn to ensure that course names, credits assigned, course aims, and learning objectives aligned and were appropriately stair-cased within learning streams, and aligned with the future curriculum direction and intent. This was achieved by the development of dedicated stream meetings that were attended by course coordinators and at least one member of the CRT to ensure consistency. The resulting outcomes meant significant changes to predominantly all our theory courses in order to contemporise their content and course delivery models. There was also a welcome revisit of clinical courses, how they are facilitated and coordinated to ensure they were fit for purpose across the $\mathrm{BN}$ programme.

It was at this stage we discussed a gap in clinical experience that had been identified in stakeholder feedback which needed to be addressed. This involved a complete shift in the Year 2 clinical courses to incorporate a Senior Persons Health course, which meant this specialist area of nursing was removed from Year I where the learners have not had the learning, experiences or time to develop the necessary skills to engage in this complex area of practice. It was also an opportunity to strengthen the Pharmacology course in Year I, by increasing the credits for this course and aligning the learning outcomes with other Year I theory and clinical courses for consistency. The input from our Learning and Teaching Development CRT member was crucial to the success of this stage. Her ability to examine across courses and provide feedback with a critical eye ensured consistency of wording, phrasing and taxonomy across Level 5, 6 and 7 courses.

The resulting changes were incorporated into a document, and with the input of the Quality Enhancement Centre (QEC) prepared for presentation to Academic Board for approval. Part of this process was the need for NCNZ to provide approval of changes. These were summarised and approval sought and received prior to external review with NZQA and TEC. 


\section{Context \\ Nursing | Global Nursing}

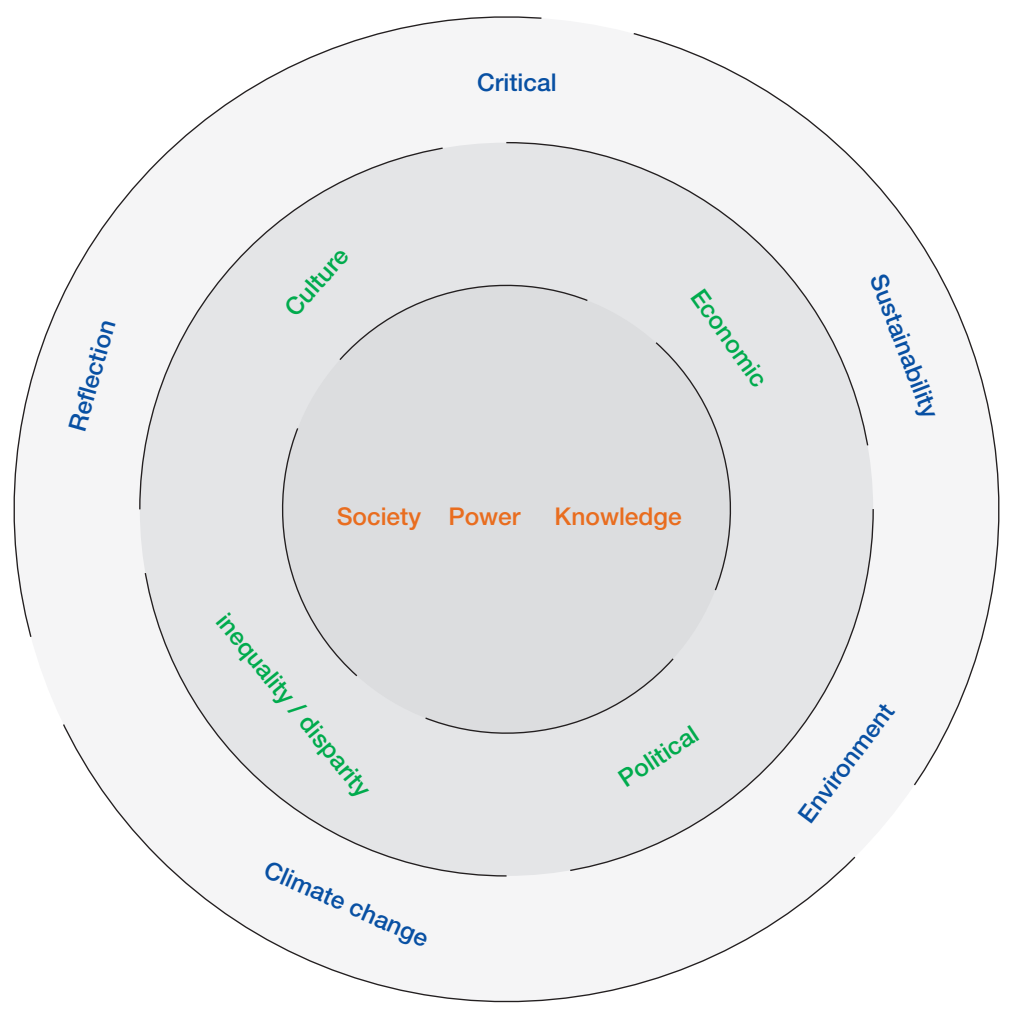

Figure 6. Final Otago Polytechnic School of Nursingframework for practice.

\section{DISCUSSION}

A curriculum philosophy represents a belief system within the discipline (Mackintosh-Franklin, 2017; Elliott, Rees, Shackell, \& Walker, 2017; M. Mansor, R. Mansor, Jusoh, \& Chin Choon, 2018) and context of nursing at OP. It enables the articulation of the roles of the nurse, beliefs about health and wellbeing, and the underlying theories that ensure that individuals, families, and communities can be confident in the competence, professionalism and safety of graduates. "A well written philosophy will guide what is taught and how it will be taught" (McCoy \& Anema, 2018, p24).

One of the key outcomes of this review was the realisation of the complexity that surrounds critical social theory, which has been well documented in the literature (How, 2017; Weaver \& Olson, 2006). The standing description had been in the curriculum for around 20 years and was lengthy, hard to understand for most of the SoN team, and difficult to articulate to each other and our learners. The resulting round table discussions about a potential philosophical change were focussed on generating outcomes rather than doing what we have always done. To challenge the long-standing backbone of the curriculum meant having some courageous conversations, being prepared to answer questions, rationalising the need for change, and contemporising our philosophical position. 
All nursing curricula in New Zealand are approved by NCNZ and all must show evidence of how learners are supported and staircased into being able to meet the competencies for Registered Nurses (RNs) by the end of their degree. Bridging the theory to practice gap was discussed in depth during this review, and this is where it became evident that the inclusion of clinical judgement (Lasater, 2007) and clinical reasoning (LevettJones et al., 2010) theories being embedded throughout the degree were crucial to our ongoing success. These theories provided an excellent template for enhanced learning and meaningful outcomes. Adapted versions of the competencies became the learning outcomes for clinical courses and these enable the learner to demonstrate growth in their clinical competence as they proceed through their degree. The introduction of clinical judgement and clinical reasoning into all courses would ensure a seamless transition into clinical practice where these theories are applied and measured.

The measurement of learner progress throughout both theory and clinical courses can be achieved very successfully with the inclusion of the Tanner $(2006,2010)$ clinical judgement rubric (Figure 7 ) and Levett-Jones et al. (2010) clinical reasoning cycle (Figure 8). Both tools allow for individuals to develop their practice from whatever their starting point. Individual life experiences, previous healthcare encounters, personal perspectives and the cultural lens of our learners all provide an individualised canvas on which they develop their core knowledge, skill acquisition and competence in relation to nursing practice.

This is illustrated when the Tanner $(2006,2010)$ rubric (Figure 7), is applied to the learner journey throughout the nursing degree. Some learners are able to practise at a more advanced level than their peers from the outset. It is essential to provide learners the ability to articulate and integrate knowledge and to demonstrate growth at their own pace and level throughout the BN programme. This reduces the need to compare themselves against others as it is an individual personal and professional journey. Integrating both the clinical judgement (Lasater, 2007) and clinical reasoning (Levett-Jones et al, 2010; Pitt, Levett-Jones, \& Hunter, 2015) theories across the three year BN programme allows learners to demonstrate their developing competence, and therefore these theories became the ultimate outcome of the revised curriculum.

\begin{tabular}{|c|c|c|c|c|}
\hline Dimension & Exemplary & Accomplished & Developing & Beginning \\
\hline \multicolumn{5}{|l|}{ Effective noticing involves: } \\
\hline Focused observation & $\begin{array}{l}\text { Focuses observation } \\
\text { appropriately; regularly observes } \\
\text { and monitors a wide variety of } \\
\text { objective and subjective data to } \\
\text { uncover any useful information }\end{array}$ & $\begin{array}{l}\text { Regularly observes and monitors } \\
\text { a variety of data, including both } \\
\text { subjective and objective; most } \\
\text { useful information is noticed; } \\
\text { may miss the most subtle signs }\end{array}$ & $\begin{array}{l}\text { Attempts to monitor a variety of } \\
\text { subjective and objective data but } \\
\text { is overwhelmed by the array of } \\
\text { data; focuses on the most } \\
\text { obvious data, missing some } \\
\text { important information }\end{array}$ & $\begin{array}{l}\text { Confused by the clinical situation } \\
\text { and the amount and kind of } \\
\text { data; observation is not } \\
\text { organized and important data } \\
\text { are missed, and/or assessment } \\
\text { errors are made }\end{array}$ \\
\hline $\begin{array}{l}\text { Recognizing deviations } \\
\text { from expected patterns }\end{array}$ & $\begin{array}{l}\text { Recognizes subtle patterns and } \\
\text { deviations from expected } \\
\text { patterns in data and uses these } \\
\text { to guide the assessment }\end{array}$ & $\begin{array}{l}\text { Recognizes most obvious } \\
\text { patterns and deviations in data } \\
\text { and uses these to continually } \\
\text { assess }\end{array}$ & $\begin{array}{l}\text { Identifies obvious patterns and } \\
\text { deviations, missing some } \\
\text { important information; unsure } \\
\text { how to continue the assessment }\end{array}$ & $\begin{array}{l}\text { Focuses on one thing at a time } \\
\text { and misses most patterns and } \\
\text { deviations from expectations; } \\
\text { misses opportunities to refine } \\
\text { the assessment }\end{array}$ \\
\hline Information seeking & $\begin{array}{l}\text { Assertively seeks information to } \\
\text { plan intervention: carefully } \\
\text { collects useful subjective data } \\
\text { from observing and interacting } \\
\text { with the patient and family }\end{array}$ & $\begin{array}{l}\text { Actively seeks subjective } \\
\text { information about the patient's } \\
\text { situation from the patient and } \\
\text { family to support planning } \\
\text { interventions; occasionally does } \\
\text { not pursue important leads. }\end{array}$ & $\begin{array}{l}\text { Makes limited efforts to seek } \\
\text { additional information from the } \\
\text { patient and family; often seems } \\
\text { not to know what information to } \\
\text { seed and/or pursues unrelated } \\
\text { information }\end{array}$ & $\begin{array}{l}\text { Is ineffective in seeking } \\
\text { information; relies mostly on } \\
\text { objective data; has difficulty } \\
\text { interacting with the patient and } \\
\text { family and fails to collect } \\
\text { important subjective data }\end{array}$ \\
\hline \multicolumn{5}{|c|}{ Effective interpreting involves: } \\
\hline Prioritizing data & $\begin{array}{l}\text { Focuses on the most relevant } \\
\text { and important data useful for } \\
\text { explaining the patient's condition }\end{array}$ & $\begin{array}{l}\text { Generally focuses on the most } \\
\text { important data and seeks further } \\
\text { relevant information but also } \\
\text { may try to attend to less } \\
\text { pertinent data }\end{array}$ & $\begin{array}{l}\text { Makes an effort to prioritize data } \\
\text { and focus on the most important, } \\
\text { but also attends to less relevant } \\
\text { or useful data }\end{array}$ & $\begin{array}{l}\text { Has difficulty focusing and } \\
\text { appears not to know which data } \\
\text { are most important to the } \\
\text { diagnosis; attempts to attend to } \\
\text { all available data }\end{array}$ \\
\hline Making sense of data & $\begin{array}{l}\text { Even when facing complex, } \\
\text { conflicting, or confusing data, is } \\
\text { able to (a) note and make sense } \\
\text { of patterns in the patient's data, } \\
\text { (b) compare these with known } \\
\text { patterns (from the nursing } \\
\text { knowledge base, research, } \\
\text { personal experience, and } \\
\text { intuition), and (c) develop plans } \\
\text { for interventions that can be } \\
\text { justified in terms of their } \\
\text { likelihood }\end{array}$ & $\begin{array}{l}\text { In most situations, interprets the } \\
\text { patient's data patterns and } \\
\text { compares with known patterns to } \\
\text { develop an intervention plan and } \\
\text { accompanying rationale; the } \\
\text { exceptions are rare or in } \\
\text { complicated cases where it is } \\
\text { appropriate to seek the guidance } \\
\text { of a specialist or a more } \\
\text { experience nurse }\end{array}$ & $\begin{array}{l}\text { In simple, common, or familiar } \\
\text { situations, is able to compare the } \\
\text { patient's data patterns with } \\
\text { those know and to develop or } \\
\text { explain intervention plans; has } \\
\text { difficulty, however, with even } \\
\text { moderately difficult data or } \\
\text { situations that are within the } \\
\text { expectations of students; } \\
\text { inappropriately requires advice } \\
\text { or assistance }\end{array}$ & $\begin{array}{l}\text { Even in simple, common, or } \\
\text { familiar situations, has difficulty } \\
\text { interpreting or making sense of } \\
\text { data; has trouble distinguishing } \\
\text { among competing explanations } \\
\text { and appropriate interventions, } \\
\text { requiring assistance both in } \\
\text { diagnosing the problem and } \\
\text { developing in intervention. }\end{array}$ \\
\hline \multicolumn{5}{|c|}{ Effective responding involves: } \\
\hline Calm, confident manner & $\begin{array}{l}\text { Assumes responsibility; } \\
\text { delegates team assignments; } \\
\text { assesses patients and reassures } \\
\text { the and their families. }\end{array}$ & $\begin{array}{l}\text { Generally displays leadership and } \\
\text { confidence and is able to control } \\
\text { or calm most situations; may } \\
\text { show stress in particularly } \\
\text { difficult or complex situations }\end{array}$ & $\begin{array}{l}\text { Is tentative in the leader role; } \\
\text { reassures patients and families } \\
\text { in routine and relatively simple } \\
\text { situations, but becomes stressed } \\
\text { and disorganized easily }\end{array}$ & $\begin{array}{l}\text { Except in simple and routine } \\
\text { situations, is stressed and } \\
\text { disorganized, lacks control, } \\
\text { makes patients and families } \\
\text { anxious or less able to cooperate }\end{array}$ \\
\hline
\end{tabular}




\begin{tabular}{|c|c|c|c|c|}
\hline Clear communication & $\begin{array}{l}\text { Communicates effectively; } \\
\text { explains interventions; calms } \\
\text { and reassures patients and } \\
\text { families; directs and involves } \\
\text { team members, explaining and } \\
\text { giving directions for } \\
\text { understanding }\end{array}$ & $\begin{array}{l}\text { Generally communicates well; } \\
\text { explains carefully to patients; } \\
\text { gives clear directions to team; } \\
\text { could be more effective in } \\
\text { establishing rapport }\end{array}$ & $\begin{array}{l}\text { Shows some communication } \\
\text { ability (e.g., giving directions); } \\
\text { communication with patients } \\
\text { families, and team members is } \\
\text { only partly successful; displays } \\
\text { caring but not competence }\end{array}$ & $\begin{array}{l}\text { Has difficulty communicating; } \\
\text { explanations are confusing; } \\
\text { directions are unclear or } \\
\text { contradictory' patients and } \\
\text { families are made confused or } \\
\text { anxious and are not reassured }\end{array}$ \\
\hline $\begin{array}{l}\text { Well-planned } \\
\text { intervention/flexibility }\end{array}$ & $\begin{array}{l}\text { Interventions are tailored for the } \\
\text { individual patient; monitors } \\
\text { patient progress closely and is } \\
\text { able to adjust treatment as } \\
\text { indicated by patient response }\end{array}$ & $\begin{array}{l}\text { Develops interventions on the } \\
\text { basis of relevant patient data; } \\
\text { monitors progress regularly but } \\
\text { does not expect to have to } \\
\text { change treatments }\end{array}$ & $\begin{array}{l}\text { Develops interventions on the } \\
\text { basis of the most obvious data; } \\
\text { monitors progress but is unable } \\
\text { to make adjustments as } \\
\text { indicated by the patient's } \\
\text { response }\end{array}$ & $\begin{array}{l}\text { Focuses on developing a single } \\
\text { intervention, addressing a likely } \\
\text { solution, but it may be vague, } \\
\text { confusing, and/or incomplete; } \\
\text { some monitoring may occur }\end{array}$ \\
\hline Being skilful & $\begin{array}{l}\text { Shows mastery of necessary } \\
\text { nursing skills }\end{array}$ & $\begin{array}{l}\text { Displays proficiency in the use of } \\
\text { most nursing skills; could } \\
\text { improve speed or accuracy }\end{array}$ & $\begin{array}{l}\text { Is hesitant or ineffective in using } \\
\text { nursing skills }\end{array}$ & $\begin{array}{l}\text { Is unable to select and/or } \\
\text { perform nursing skills }\end{array}$ \\
\hline \multicolumn{5}{|c|}{ Effective reflecting involves: } \\
\hline Evaluation/self-analysis & $\begin{array}{l}\text { Independently evaluates and } \\
\text { analyzes personal clinical } \\
\text { performance, noting decision } \\
\text { points, elaborating alternatives, } \\
\text { and accurately evaluation } \\
\text { choices against alternatives }\end{array}$ & $\begin{array}{l}\text { Evaluates and analyzes personal } \\
\text { clinical performance with minimal } \\
\text { prompting, primarily about major } \\
\text { events or decisions; key decision } \\
\text { points are identified, and } \\
\text { alternatives are considered }\end{array}$ & $\begin{array}{l}\text { Even when prompted, briefly } \\
\text { verbalizes the most obvious } \\
\text { evaluations; has difficulty } \\
\text { imagining alternative choices; is } \\
\text { self-protective in evaluating } \\
\text { person choices }\end{array}$ & $\begin{array}{l}\text { Even prompted evaluations are } \\
\text { brief, cursory, and not used to } \\
\text { improve performance; justifies } \\
\text { personal decisions and choices } \\
\text { without evaluating them }\end{array}$ \\
\hline $\begin{array}{l}\text { Commitment to } \\
\text { improvement }\end{array}$ & $\begin{array}{l}\text { Demonstrates commitment to } \\
\text { ongoing improvement; reflects } \\
\text { on and critically evaluates } \\
\text { nursing experiences; accurately } \\
\text { identifies strengths and } \\
\text { weaknesses and develops } \\
\text { specific plans to eliminate } \\
\text { weaknesses }\end{array}$ & $\begin{array}{l}\text { Demonstrates a desire to } \\
\text { improve nursing performance; } \\
\text { reflects on and evaluates } \\
\text { experiences; identifies strengths } \\
\text { and weaknesses; could be more } \\
\text { systematic in evaluating } \\
\text { weaknesses }\end{array}$ & $\begin{array}{l}\text { Demonstrates awareness of the } \\
\text { need for ongoing improvement } \\
\text { and makes some effort to learn } \\
\text { from experience and improve } \\
\text { performance but tends to state } \\
\text { the obvious and needs external } \\
\text { evaluation }\end{array}$ & $\begin{array}{l}\text { Appears uninterested in } \\
\text { improving performance or is } \\
\text { unable to do so; rarely reflects; } \\
\text { is uncritical of himself or herself } \\
\text { or overly critical (given level of } \\
\text { development); is unable to see } \\
\text { flaws or need for improvement }\end{array}$ \\
\hline
\end{tabular}

Figure 7. Clinical Judgement Rubric, (Lasater, 2007).

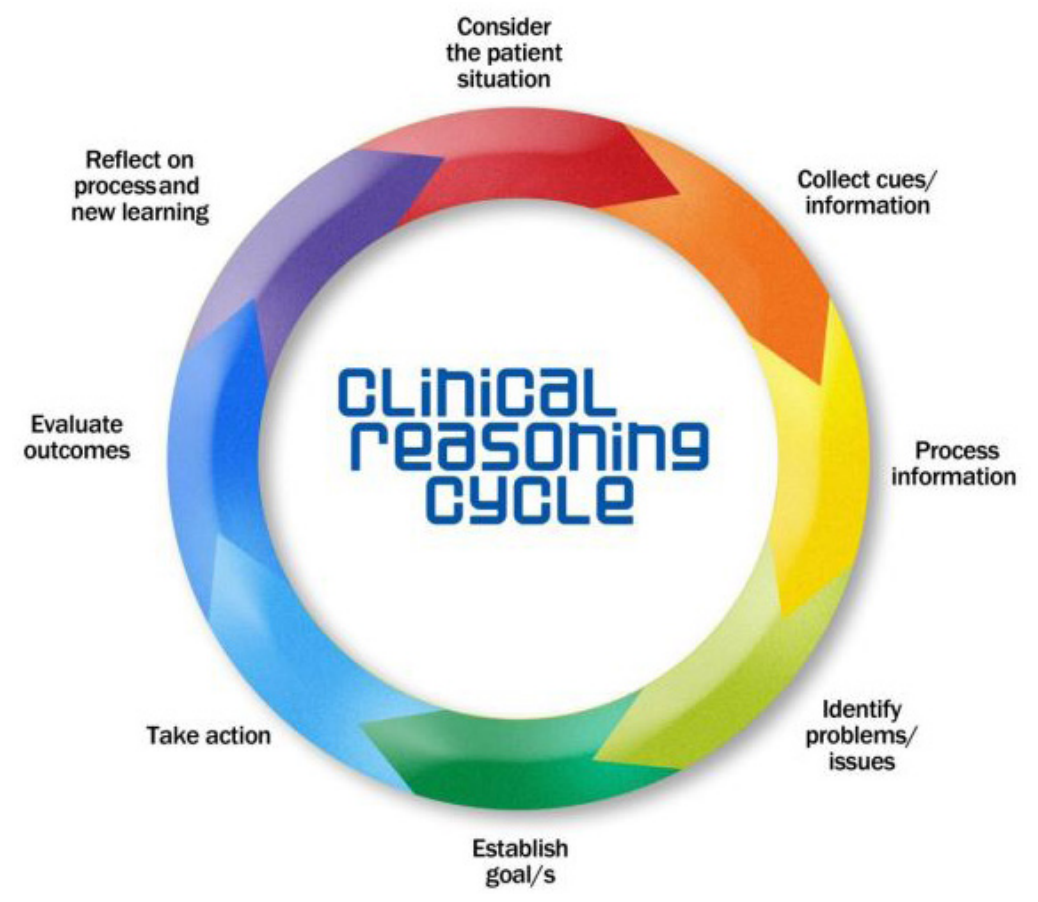

Figure 8. Clinical Reasoning Cycle, (Levett-Jones et al., 2010). 
Nursing requires the development of essential core knowledge, skills and professional understanding (van Graan, Williams, \& Koen, 2016). The C. Tanner (2006) and Lasater (2007) tools enable academics to assess a learner's progress accurately and provide further opportunities for developing and learning. Combined with the clinical reasoning cycle (Levett-Jones et al., 2010, Levett-Jones, 2015) which guides the learner to make clinical decisions that are informed and are evidence based, it will overall improve patient outcomes (Birks, Bagley, Park, Burkot, \& Mills, 2017). Areas of concern can be addressed early with gaps in knowledge identified. The complexity of the learning and the thinking and judgement required can be staircased, ensuring that by the end of their degree, learners meet the competencies for RNs (NCNZ, 2012).

Over previous iterations of the BN curriculum, we have been very proactive in ensuring that Te Tiriti o Waitangi, sustainability, health \& safety, the rural perspective and the New Zealand context are fully integrated into all courses. We are satisfied that with the changes to the curriculum that these key themes will be further strengthened and that learners will be able to articulate their knowledge of these with greater clarity and understanding.

Furthermore, the $\mathrm{WHO}$ has identified that working inter-professionally in the healthcare team is the most effective pathway to improving patient care and outcomes (World Health Organisation, 20I0). This is an area of our curriculum that has been further enhanced recently, through a collaboration with our University of Otago inter-professional colleagues which provides several opportunities for our learners at OP to engage in interprofessional learning opportunities throughout their $\mathrm{BN}$ programme. We have also developed a formalised clinical coaching model for our third-year nursing students to regularly engage in the learner journey of their junior peers, as it is a NCNZ competency for a registered nurse to be able to direct and delegate others.

Our nursing curriculum philosophy is closely aligned with NCNZ competencies for RNs, UN sustainable development goals, the WHO targets, NZQA and TEC, and OP's mission statement, values and goals. This is an essential aspect of a philosophy as it ensures that the BN programme fits within the broader organisational context supporting stakeholders' needs.

We are confident that the curriculum we have developed is robust enough to be able to flex and change. This has been evidenced this year as COVID-19 brought about a time of uncertainty and complexity. Our new curriculum and our team were able to respond in a way that has ensured that our learners are even more prepared, that they have the knowledge and skills, and have experienced a whole new way of learning and engaging. We believe that this demonstrates resilience and adaptability, which are essential qualities for every nurse.

\section{SUMMARY}

Our team has learned some valuable lessons from this curriculum review. The development of a CRT proved highly effective. The mix of experienced academics who have been through the process in previous curriculum iterations and novice academics who have most recently been in clinical practice meant that there was a breadth of experiences that added richness to the discussions and resulting outcomes. The workload was distributed evenly across all members whilst providing a learning environment which ensured that future reviews have a team on whose knowledge they can draw upon.

Staff engagement in this process and resulting discussions forged enhanced collegial connections across the SoN and assisted staff to focus our collective efforts on both the learning and teaching experience whilst helping to prepare work-ready nursing graduates. The evolution of a curriculum philosophy was much easier when there was agreement and the rationale was explained to SoN academics who have worked under a long-standing philosophy and curriculum for many years.

Otago Polytechnic nursing graduates are sought after around the country. As per OP graduate outcomes, SoN Destination Survey and NCNZ data, we have proven longstanding success in our degree programme with greater than 90 percent retention rates of learners, consistent success in NCNZ state final examination outcomes (greater than 97 percent for the past five years) and high employment rates (I00 percent for the past five years). We know 
that our graduates make a difference to people in all communities, and for that we are extremely proud. We want to ensure that we maintain and enhance this pathway with a modern, dynamic, flexible curriculum that develops nurses who are critical thinkers with excellent clinical judgement.

Karole Hogarth is an Associate Professor and the Head of Nursing in the School of Nursing | Te Kura Tapuhi at Otago Polytechnic Te Kura Matatini ki Otago. Clinically she has worked nationally and internationally in a range of settings, mainly in Burn Units and Intensive Care Units. Karole has 15 years' experience as a nurse academic mainly teaching the sciences in health courses. Her research focus is on inter-professional education, science in the health professions, and improving outcomes for Māori learners.

(D) https://orcid.org/0000-0002-5764-6289

Donna Burkett is a Registered Nurse and Senior Lecturer at the Otago Polytechnic | Te Kura Matatini ki Otago. Donna has practised predominantly in child and youth health care contexts both in New Zealand and internationally over her career and she joined the School of Nursing | Te Kura Tapuhi academic team in 2017. As a proud Otago Polytechnic nursing graduate herself, her teaching role allows her to give back to the nursing community by helping promote learner centredness, learner experience with resulting learner outcomes that help prepare work ready nursing graduates that truly make a difference.

(D) https://orcid.org/0000-0003-3122-9804

\section{REFERENCES}

Birks, M., Bagley, T., Park, T., Burkot, C., \& Mills, J. (2017). The impact of clinical placement model on learning in nursing: A descriptive exploratory study. Australian Journal of Advanced Nursing, 34(3), 16-23.

Elliott, S., Rees, G., Shackell, E., \& Walker, J. (2017). Making it work - A BSN faculty's process of curriculum redesign. International Journal of Nursing Education Scholarship, I-9. https://doi.org/I0.15I5/ijnes-2016-0057

How, A. (2017). Critical Theory. New York, USA: Palgrave Macmillan.

Lasater, K. (2007). Clinical Judgment Development: Using Simulation to Create an Assessment Rubric. Journal of Nursing Education, 46, 496-503.

Levett-Jones, T. (2015). The Clinical Placement: An essential guide for nursing students (4th ed). NSW, Australia: Elsevier.

Levett-Jones, T., Hoffman, K., Dempsey, J., Yeun-Sim Jeong, S., \& Noble, D. (2010). The 'five rights' of clinical reasoning: An educational model to enhance nursing students' ability to identify and manage clinically 'at risk' patients. Nurse Education Today, 30, 515-520.

Mackintosh-Franklin, C. (2017). Nursing Philosophy: A review of current pre-registration curricula in the UK. Nurse Education Today, 37, p7I-74.

Mansor, M., Mansor, R., Jusoh, A., \& Chin Choon, L. (2018). The future of nursing curriculum for new learning environment. Malaysian Journal of Medical Research, 2(2), 47-57.

McCoy, J., \& Anema, M. (2018). Fast facts for curriculum development in nursing: How to develop and evaluate educational programmes (2nd ed). USA: Springer.

Nursing Council of New Zealand. (2012). Competencies for Registered Nurses. Wellington, New Zealand: Author.

Otago Polytechnic School of Nursing. (2020) Destination Survey. 2014-2019. Dunedin, New Zealand: Author.

Pitt, V., Levett-Jones, T., \& Hunter, S. (20I5). The influence of critical thinking skills on performance and progression in a preregistration nursing program. Nurse Education Today, 35, 125-131.

Tanner, C. (2006). Thinking Like a Nurse: A Research-Based Model of Clinical Judgment in Nursing. Journal of Nursing Education, 45(6), 204-211.

Tanner, T. (2010). Transforming prelicensure nursing education: Preparing the new nurse to meet emerging health care needs. Nursing Education Perspectives, 3I(6), 347-35I.

van Graan, A., Williams, M., \& Koen, M. (2016). Professional nurses understanding of clinical judgment: A contextual inquiry. Health SA Gesondheid, 21, 280-293.

Weaver, K. \& Olson, J. (2006). Understanding paradigms used for nursing research. Integrative Literature Reviews \& Meta-Analyses, 459-469.

World Health Organisation. (2010). Framework for action on interprofessional education collaborative practice. Retrieved from https://www.who.int/hrh/resources/framework_action/en/ 